Gönderilme Tarihi: 15 Ağustos 2016

Kabul Tarihi: 21 Kasım 2016

\title{
KÜLTÜREL MİRASIN SÜRDÜRÜLEBİLİR TURİZM ÜRÜNÜ ÇEŞİDİ OLARAK DEĞERLENDİRİLMESİ: EDİRNE ÖRNEĞİ
}

\author{
Özlem ER*, Övünç BARDAKOĞLU** \\ öz
}

Çalışmanın amacı kültür turizmi ve sahip olduğu kültürel mirasın çekim gücü ile turist kabul eden bir destinasyon olan Edirne İli'nin mevcut turizm ürünlerinin belirlenmesi, turizm ürünü çeşitlendirmesi ile birlikte sürdürülebilir bir turizm gelişimi sağlanabilmesi için öneriler sunulmasıdır. Bu doğrultuda Edirne İli'nde turizm faaliyetleri içinde yer alan kamu sektörü, özel sektör, sivil toplum kuruluşlarının temsilcilerinden oluşan 19 katılımcı ile yüz yüze mülakat tekniği kullanılarak görüşülmüş, elde edilen verilere içerik analizi uygulanmıştır. Sürdürülebilir bir turizm gelişimi için; kültürel mirasın koruma-kullanma dengesi gözetilerek değerlendirilmesi, var olan geleneksel hazinenin birer turizm ürünü çeşidi haline getirilerek turistlere sunulması ve turizmle ilgili tüm aktörlerin birlikte hareket etmesinin destinasyonun yararına olacağı ortak görüş olarak belirtilmiştir.

Anahtar Sözcükler: Turizm Ürünü, Sürdürülebilir Turizm, Kültürel Miras, Kültür Turizmi

\section{THE ASSESMENT OF CULTURAL HERITAGE AS A PRODUCT OF SUSTAINABLE TOURISM: THE CASE OF EDİRNE}

\section{ABSTRACT}

The purpose of the research is to determine current touristic products of Edirne City, which is a destination accepting many tourists by means of culture tourism and its cultural heritage, and to make suggestions for providing a sustainable touristic development through diverse touristic products. Accordingly; 19 participators consisting of representatives from public sector, private sector, nongovernmental organizations were interviewed with face-to face negotiation technique, content analysis was applied to data obtained from negotiations. Utilization of cultural heritage by paying regard to protection-use balance, presentation the existing traditional treasure to tourists after transforming them into touristic product varieties taking joint action by all actors relevant to tourism will be in favour destination for sustainable tourism development

Keywords: Touristic Product, Sustainable Tourism, Cultural Heritage, Cultural Tourism

*Gümüşhane Üniversitesi, Gümüşhane Meslek Yüksek Okulu, Turizm ve Otelcilik Programı, Gümüşhane, E-posta: erozlem_83@hotmail.com

${ }^{* *}$ Dokuz Eylül Üniversitesi, Seferihisar Fevziye Hepkon Uygulamalı Bilimler Yüksekokulu, Turizm İşletmeciliği ve Otelcilik Bölümü, İzmir, E-posta: ovunc.bardakoglu@deu.edu.tr 


\section{Kültürel Mirasın Sürdürülebilir Turizm Ürünü Çeşidi Olarak Değerlendirilmesi: Edirne Örneği}

\section{GİRİ̧̧}

Turizm sürekli gelişen ve değişen yapısıyla günümüzün en dinamik sektörlerinden biridir. Turizmin gelişmesiyle birlikte turizme kaynaklık eden doğal ve kültürel varlıklar geri döndürülemez zararlara uğramaktadır. Bu zararların önlenmesi amacıyla 1970'li yıllarda sürdürülebilir kalkınma ve buna bağlı olarak sürdürülebilir turizm kavramları ortaya çıkmıştır. Sürdürülebilir turizm, doğal ve kültürel çevreye duyarlı, gelecek kuşakların da turizmden faydalanmasını amaçlayan, uzun vadeli düşünmeyi gerektiren, yerel halkın turizmden pay almasını savunan bir turizm şeklidir.

Sürdürülebilir turizm anlayışının da etkisiyle değişen turist profilleri ile birlikte ülkeler; yönelik turizm talebinin isteklerine cevap verebilmek ve turizm gelirlerini arttırmak amacıyla yeni turizm ürünleri oluşturmak, dolayısı ile turizm ürünü çeşitlendirmesine gitmek durumunda kalmışlardır. Kültür turizmi de son yıllarda önem kazanan turizm ürünü çeşitlerinden biridir. Turistik destinasyonun sahip olduğu kültürel mirasın doğru kullanımıyla turizme kazandırıması yöre, bölge ve ülke ekonomisine ciddi katkılar sağlar.

Kültür turizmi doğal, tarihi ve kültürel mirasın gelecek kuşaklara aktarılmasında, bölgenin turizmine yönelik talep oluşturmada ve talebin arttırılmasında önemli bir etkendir. Kültür turizminin gelir attırıcı etkisinin yanında kültürel değerlerin korunması ve bölgenin potansiyelinin doğru kullanılabilmesi gibi birçok fayda sağladığı gözlenmektedir. Bunun için de tüm paydaşların işbirliği içinde çalışması ve doğru turizm politikalarının belirlenmesi en akılcı yol olacaktır. Türkiye bulunduğu konum nedeni ile farklı medeniyetlere ev sahipliği yapmış bir ülkedir. Bu nedenle kültürel anlamda sahip olduğu zenginlikleri turizmin hizmetine sunarak yüksek verim sağlaması mümkündür. Kültürel miras bakımından farklı değerleri bünyesinde barındıran illerden biri de Edirne'dir.

Edirne, kültürel açıdan zengin bir potansiyele sahip olmasına rağmen bu potansiyelini gerektiği şekilde değerlendirememekte, turizmin 12 aya yayılmasında sıkıntılar yaşanmakta ve turistler konaklama yapmadan şehirden ayrımaktadır. Bu çalışma kapsamında kültür turizminin sürdürülebilir bir şekilde geliştirilmesi amacıyla neler yapılabileceği belirlenmeye çalışımış, kültür turizmi dışında şehirde oluşturulabilecek yeni turizm ürünleri ile ilgili öneriler getirilmiş ve kültürel mirasın sürdürülebilir kullanımının sağlanması için değerlendirmelerde bulunulmuştur. 


\section{Özlem Er ve Övünç Bardakoğlu}

\section{TURİZM ÜRÜNÜ VE TURİZMDE ÜRÜN ÇEŞİTLENDİRME}

Turizm ürünü kavramı ile ilgili literatürde farklı yaklaşımlar yer almaktadır. Burkart ve Medlik (1981) turizm ürünü; dar anlamda turistin satın aldığı her şey, geniş anlamda turistin destinasyonda yaptığı her türlü etkinlik olarak açıklarken, Olalı (1982); turistin seyahati sırasında ortaya çıkan intiyaçlarını karşılayabilecek nitelikteki mal ve hizmetler karışımı olarak ifade etmiştir. Hacıoğlu (1989); destinasyonun sahip olduğu doğal, kültürel tüm kaynaklar ve turistin intiyacı olan hizmetler bütününün turizm ürününü oluşturduğunu belirtmiştir. Olalı ve Timur (1988) Olalı (1982) ile benzer şekilde turizm ürününün; turistlerin ihtiyaçlarını karşılayacak nitelikteki mal ve hizmetleri içeren bir paket olduğunu ifade etmişlerdir. Doswell (1997) ise turizm ürününün gidilen yerde konaklama süresince ziyaret edilen yerler ve yararlanılan hizmet ve olanaklardan oluştuğunu belirtmiştir.

Birbirinden farklı bu tanımların ortak noktasını turistin ihtiyac duyduğu mal ve hizmetler oluşturmaktadır. Turistler beklentilerini destinasyonun sahip olduğu çevresel ve kültürel özelliklere göre oluşturduğu için turizm ürünleri de bu doğrultuda hazırlanmalıdır (Murphy, Pritchard ve Smith, 2000). Dolayısı ile bir destinasyonda turizm faaliyetinden söz edebilmek için potansiyel tüketicilerin kullanımına uygun turizm ürünleri oluşturulmalı ve sahip olunan doğal ve kültürel kaynaklar koruma kullanma dengesi gözetilerek turizmin hizmetine sunulmalıdır. Turizm ürününün kalitesi turistin tatmin düzeyinin yükselmesi açısından son derece önemli olduğu için ürün geliştirirken destinasyonun sahip olduğu somut ve somut olmayan kaynakların iyi bir şekilde gözden geçirilmesi rasyonel olacaktır (Bramwell, 1998; Petkova ve Marinov 2014).

Turistik bir destinasyonda turizm ürünün sayısının fazlalığı hem turist sayısını arttıır hem de turizm sezonunun uzamasını sağlar. Buradan hareketle turizm ürünü çeşitlendirmesi ile tüketiciye yeni olanaklar sunularak destinasyonda kalış süresini uzatabilmek mümkündür (Sarkım, 2007). Ancak ürün çeşitlendirme çalışmalarına başlamadan destinasyonun sahip olduğu alt ve üst yapı olanakları, doğal, kültürel ve toplumsal kaynakları ile tamamlayıı hizmetlerin iyi bir şekilde analiz edilmesi ve bu doğrultuda çalışmalara yön verilmesi rasyonel olacaktır (Demir ve Demir, 2004). Ürün çeşitlendirme ve kuvvetlendirme destinasyonun uluslararası alanda rekabet gücünü arttırırken aynı zamanda sürdürülebilir bir turizm gelişimi sağlar (Benur ve Bramwell, 2015).

Turizmde etkin bir ürün çeşitlendirme faaliyeti için destinasyona uygun turizm ürünü planlaması yapılması gerekmektedir (Dinçer ve Ertuğrul, 2009). Turist profilleri tanımlanmalı, gereksinimler belirlenmeli, 


\section{Kültürel Mirasın Sürdürülebilir Turizm Ürünü Çeşidi Olarak Değerlendirilmesi: Edirne Örneği}

üreticilere yol gösterilmeli ve sürdürülebilir kalkınma ilkelerine uygun turizm ürünleri seçilmelidir (Benur ve Bramwell, 2015). Turistik destinasyonlarda sürdürülebilir turizm anlayışının benimsenmesi ile turizm faaliyetinin olası zararlarının en aza indirgenmesi ve mevcut turizm ürünlerinin gelecek nesiller tarafından kullanılabilmesi amaçlanmaktadır (Swarbrooke, 1998). Bir destinasyonun sahip olduğu önemli turizm ürünlerinden biri olan kültürel miras da sürdürülebilirlik kavramı ile hem benzer özellikler taşımakta hem de birlikte planlandığında verimli sonuçlar elde edildiği görülmektedir (Ismagilova, Safiullin ve Bagautdinova 2014).

\section{KÜLTÜREL MİRASIN SÜRDÜRÜLEBİLİRLİĞİ}

Turistlerin farklı kültürleri görüp tanımak amacıyla yaptıkları seyahatler kültür turizmi olarak adlandırıır ve turizm ürünü çeşitleri arasında en fazla talep görenlerden biri olarak değerlendirilmektedir (Saarinen, Moswete ve Monare, 2014; Uygur ve Baykan, 2007). Kültür turizmi; turiste kültürel mirasın yerinde ziyaret edilmesinin yanı sıra ev sahibi toplulukların kültürel geçmişinin öğrenilmesi ve deneyimlenmesi imkanını da sağlamaktadır (Batman ve Oğuz, 2008). Kültür turizmi yerel halkın nasıl yaşadığını, göreneklerini turiste en iyi şekilde aktaran turizm ürünü çeşididir (Saarinen vd., 2014) Kültürel miras insanoğlunun binlerce yıllık yaşam deneyiminin, aklının ve yaratıclığının günümüze ulaşmış somut ve somut olmayan değerleridir (Ünsal ve Pulhan, 2012).

Kültür turizmi kapsamında destinasyonun sahip olduğu kültürel mirasın değerlendirilmesi yaptığı ekonomik katkı ile birlikte bölgenin kalkınmasına destek sağlamaktadır. Turizm sezonunun uzatılarak yıın 12 ayına yayılması, yeni iş olanaklarının yaratılması, bölgede gelir artışının sağlanması ve destinasyonun bilinirliğinin uluslararası piyasada artması açısından kültürel miras turizmi diğer turizm ürünü çeşitlerine göre bir adım öne çıkmaktadır (Li ve Hunter, 2015; Loulanski ve Loulanski, 2011). Turizm ve kültür arasındaki karşılıklı ilişkiye bağlı olarak; turizmin sürekliliği için doğal ve kültürel kaynakların korunması, geliştirilmesi son derece önem taşımaktadır (Uslu ve Kiper, 2006). Tarihi ve kültürel değerlerin koruma altına alınması, restore edilmesi, bakımlarının düzenli olarak yapılması söz konusu destinasyonda turizm faaliyetinin sürdürülebilir bir şekilde planlanması ile daha mümkün hale gelmektedir.

Sürdürülebilirlik, mevcut varlıkların gelecek kuşaklara aktarılması iken; kültürel miras, geçmişten gelen turizm merkezli varlıkları ifade etmektedir (Özdoğan, 2014). Destinasyonların sahip olduğu tarihi ve kültürel miras söz konusu bölgede turizm gelişimi için önem arz etmektedir 


\section{Özlem Er ve Övünç Bardakoğlu}

(Ismagilova vd., 2014). Turizmin sürdürülebilir gelişiminin sağlanması ile olumsuz etkilerin aza indirilmesi ve olumlu etkilerin üst düzeye çıkarılması bütün turistik alanlar için istenen bir sonuçtur. Bu kapsamda, turizme konu olan varlıkların gelecek kuşaklara aktarılacak şekilde korunması ve geliştirilmesi, kısaca sürdürülebilirliğin sağlanması rasyonel bir davranış olacaktır. Sürdürülebilir kültür turizmi planlaması yapııırken; destinasyonun sahip olduğu kültürel mirasın doğru bir şekilde belirlenmesi ve sürdürülebilirlik anlayışı içerisinde yönetilmesi gerekmektedir (Du Cros, 2001). Geçmişten gelen kültürel varlıkların çoğaltılamaması, turist sayısındaki artış ve turizm ürününün sıradanlaşması, kültür turizminin dengesiz bir şekilde aşırı büyümesine yol açmaktadır. Bu durum bilinçli kullanım ve sürdürülebilirlik sorununu beraberinde getirmekte ve kaynakların sürdürülebilir bir biçimde kullanımının önemini her geçen gün daha da arttırmaktadır (Chhabra, 2009).

Destinasyonda etkin bir kültür turizmi gelişiminden söz edebilmek için kültür, miras ve turizmin birbiriyle bağlantılı ve doğru yönetilmesi gerekmektedir (Çekül Vakfı, 2012; Dedehayır, 2014). Ancak planlama yapılırken her bölgenin sahip olduğu turizm kaynaklarının envanterinin çıkarılması, bu doğrultuda çözümler sunulması ve bölgeler arası gelişme farklılıklarına yol açmayacak planların hazırlanması akılcı olacaktır. Bu süreçte de turist, özel sektör, kamu sektörü, yerel halk, yerel yönetimler, bölgesel ve uluslararası örgütler ve üniversitelerin birlikte hareket etmesi kültür turizminin sürdürülebilirlik anlayışı içerisinde gelişmesine işlerlik kazandıracaktır (Mowforth ve Munt, 1998).

Kültürel mirasın dolayısı ile destinasyonun sahip olduğu kaynakların turizmin olumsuz etkilerinden zarar görmesini önleyebilmek adına sosyal, çevresel, ekonomik, kültürel sürdürülebilirlik ilkelerinin bir arada benimsenmesi turizm paydaşları tarafından dikkatle üzerinde durulması gereken konular arasındadır (Du Cros, 2001; Loulanski ve Loulanski, 2011; Mowforth ve Munt, 1998).

\section{YÖNTEM}

Konu ile ilgili literatür taramasına dayanarak hazırlanan araştırmanın amacl; kültür turizmi ve sahip olduğu kültürel mirasın çekim gücü ile turist kabul eden bir destinasyon olan Edirne ilinin mevcut turizm ürünlerinin belirlenmesi ve sürdürülebilir bir turizm gelişimi için yapılması gerekenler hakkında öneriler sunulmasıdır. Bu amaç doğrultusunda çalışmanın araştırma sorusu; "Edirne'de kültürel miras turizmi kapsamında mevcut turizm ürünlerinin belirlenmesi, çeşitlendirilmesi ve kültür turizminin sürdürülebilir gelişimi için neler yapılması gerekmektedir?" olarak 


\section{Kültürel Mirasın Sürdürülebilir Turizm Ürünü Çeşidi Olarak Değerlendirilmesi: Edirne Örneği}

belirlenmiştir. Araştırma sorusu kapsamında bilgi edinebilmek amacıyla Edirne ilinde turizm alanında görev alan yerel yönetim, kamu sektörü, özel sektör, sivil toplum kuruluşları ve üniversite temsilcilerinden oluşan 19 kişi ile nitel veri toplama tekniklerinden yüz yüze mülakat yöntemi kullanılarak görüşme sağlanmıştır. Çalışmada nitel bir veri toplama yönteminin tercih edilmesinin nedeni konu ile ilgili derinlemesine bilgi edinme gerekliliğidir ve bunun da ancak ilgili kurum temsilcileri ile yüz yüze görüşülerek mümkün olacağı düşünülmüştür. Görüşme sağlanan katılımcıların listesi çalışmanın ekinde verilmiştir.

Araştırma evrenini tüm bu kuruluşlarda çalışan kişiler oluştururken, örneklemin belirlenmesinde amaçı örnekleme yöntemlerinden maksimum çeşitlilik örneklemesi kullanılmışıı. (Yıldırım ve Şimşek, 2008). Bu örnekleme yöntemiyle göreli olarak daha küçük bir çalışma alanı yaratıııken, araştırmanın amacına uygun şekilde çeşitli katıımcılarla görüşme sağlanabilmektedir. Çalışma kapsamındaki görüşmeler 2015 yılının Mayıs ayında gerçekleştirilmiştir. Edirne İli'nde turizm alanında çalışan 22 kişiden randevu talep edilmiş, 3 kişinin görüşmeyi işlerinin yoğunluğunu gerekçe göstererek kabul etmemesi nedeniyle 19 katılımcı ile kendi ofislerinde görüşme sağlanabilmiştir. Araştırma sorusuna yanıt ararken katılımcılara yöneltilen sorular şu şekildedir:

1) Edirne'deki mevcut turistik ürünler nelerdir?

2) Turistik ürün çeşitlendirme amacıyla neler yapılıyor ve yapılmalıdır?

3) Kültürel mirasın sürdürülebilirliği konusunda ne gibi çalışmalar yapiliyor?

4) Kültür turizmini geliştirmek ve daha fazla turist gelmesini sağlamak için neler yapılmalıdır?

Görüşmeler ortalama 25-80 dakika arasında sürmüş, katılımcıların izni ile ses kaydı alınmış ve notlar tutulmuştur. Arial 11 punto ve 1,5 satır aralığı kullanılarak yazılı hale getirilen ses kayıtlarından 72 sayfalık (A4 boyutunda) bir veri seti elde edilmiş ve içerik analizi yapılmışırı. İçerik analizi ile temalar belirlenmiş ve temalar altında kodlar oluşturulmuştur (Kozak, 2014). Çalışmanın geçerlik ve güvenirliğini sınamak amacıyla görüşmeler sonucunda elde edilen veri seti üzerinde bağımsız iki akademisyenin tema ve kodları belirlemeleri istenmiş ve araştırmacıların oluşturduğu tema ve kodlarla karşılaştırımıştır. Ortaya çıkan tema ve kodlar arasında \%75' ten fazla benzerlik olduğu saptanmıştır. Ayrıca araştırma kapsamında elde edilen verilerin güvenirliğini arttırmak, yanlılığı azaltmak, araştırma sonucunda ortaya çıkan tema ve kodlar arasında 


\section{Özlem Er ve Övünç Bardakoğlu}

karşılaştırma yapabilmek için sayısallaştırma tekniğinden de yararlanıımıştır (Yıldırım ve Şimşek, 2008).

\section{BULGULAR}

Çalışmaya katılan Edirne İli'nde turizm alanında görev alan kişilerle yapılan görüşmeler sonucunda elde edilen bulgular, belirlenen tema ve kodlarla ilgili açıklamalar şu şekildedir.

\section{Mevcut Turizm Ürünleri}

Katılımcların Edirne' de bulunan turizm ürünleriyle ilgili değerlendirmelerinde; tarihi eserler $(\% 68,4)$, yemek kültürü $(\% 68,4)$, Selimiye Camii ve Külliyesi $(\% 47,3)$, geleneksel el sanatları $(\% 36,8)$, Kırkpınar Yağlı Güreşleri $(\% 31,5)$, inanç turizmi $(31,5)$, II. Bayezid Külliyesi ve Sağlık Müzesi $(\% 31,5)$ ile öne çıkmaktadır.

\section{Tablo 1: Mevcut Turizm Ürünleri}

\begin{tabular}{|l|l|}
\hline Kullanılan İfadeler & n \\
\hline 1.Tarihi Eserler & 13 \\
\hline 2. Yemek Kültürü & 13 \\
\hline 3. Selimiye Camii Ve Külliyesi & 9 \\
\hline 4. Geleneksel El Sanatları & 7 \\
\hline 5. Kırkpınar Yağlı Güreşleri & 6 \\
\hline 6. İnanç Turizmi & 6 \\
\hline 7. II. Bayezid Külliyesi ve Sağlık Müzesi & 6 \\
\hline
\end{tabular}

Katılımcılar mevcut turizm ürünlerini değerlendirirken Edirne'nin tarihi geçmişinin önemini vurgulamışlar ve Edirne turizminin kaynağını tarihi ve kültürel varlıkların oluşturduğunu belirtmişlerdir. Edirne'nin Traklardan başlayarak Makedonya, Roma, Bizans ve Osmanlı uygarlıklarına ev sahipliği yapması ayrıca Osmanlı İmparatorluğu'nun 92 yıl boyunca başkenti olması nedeniyle kentte çok sayıda Osmanlı'ya ait eser olduğu ifade edilmiştir.

Görüşme 3: "Trak, Makedon, Roma ve Osmanlı egemenliğine giren Edirne, Osmanlı İmparatorluğu için her daim idari bir merkez, Balkan coğrafyasını içine alan geniş bir bölgede ise askeri, sanayi, ticari, kültür ve sanat merkezi olarak hakimiyet noktası olmuştur. Şehrin jeostratejik yapısı, tarihi ve kültürel kimliği Osmanlı mimarisinin erken ve klasik dönem şaheserlerinin burada inşa edilmesinde belirleyici bir rol oynamıştır." 


\section{Kültürel Mirasın Sürdürülebilir Turizm Ürünü Çeşidi Olarak Değerlendirilmesi: Edirne Örneği}

Mevcut turizm ürünleriyle ilgili ön plana çıkan kategorilerden birini de yeme - içme faaliyetlerini içeren gastronomi oluşturmaktadır. Edirne'nin geleneksel mutfağında; Edirne tava ciğeri, Edirne köftesi, elbasan tava, mamzana, karnıyarık, beyaz peynir, badem ezmesi, Kavala kurabiyesi ve deva -i misk helvası yer almaktadır. Bu yiyecekler Türk ve Osmanlı mutfağının izlerini taşımakla birlikte aynı zamanda Rum ve Yahudi mutfağından da dokunuşlar içermektedir. Edirne kültürünün ve mirasının bir parçasını oluşturan Edirne yemeklerini deneme amacıyla birçok turistin Edirne'yi ziyaret ettiği ve özellikle Edirne Saray Mutfağı lezzetlerinin tadına bakmak için gastronomi turları ile Edirne'ye geldiği katılımcılar tarafından belirtilmiştir.

Dünyada birçok kültür turistinin UNESCO eserlerini görmek amacıyla eserlerin bulunduğu kentlere gittiği, Edirne'nin de bu sayede turist çektiği katılımcılar tarafından ifade edilmiştir. 2010 yılında Kırkpınar Yağı Güreşleri'nin UNESCO Somut Olmayan Kültürel Miras Listesi'ne ve 2011 yılında Selimiye Camii ve Külliyesi'nin UNESCO Dünya Miras Listesi'ne girmesi ile Edirne'nin dünya çapında bilinirliğinin artması, şehirde geceleme sayısını yükseltmiş, özellikle Kanada ve Japonya gibi uzak ülkelerden gelen gelir düzeyi yüksek kültür turistlerinin çoğalmasını sağlamıştır.

Edirne kültürü ve mirasını tanımak için geleneksel el sanatlarının da bilinmesi gerektiği katılımcılar tarafından ifade edilmiştir. Bunların içinde; ahşap üzerine oyma şeklinde yapılan ve birçok objeye uygulanabilen ve Topkapı Sarayı kapılarının örnek oluşturduğu Edirnekari (Edirne işi) sanatını, İstanbul ile ortak ürün olarak UNESCO Somut Olmayan Kültür Mirası Listesinde yer alan ebru sanatı, çini, aynalı süpürge, mis sabunu (meyve sabunu) ve ipek böceği kozacılığının en güzel örnekler olduğunu vurgulamışlardır. Bu ürünler turistler tarafından hediyelik eşya olarak talep görmektedir.

Görüşme 11: "Şehirde geleneksel el sanatlarının yaşatılabilmesi ve yerel halka istihdam yaratılması amacılla kurslar açılmakta ve kursiyerler tarafindan yapılan eserler sergilenerek satışa sunulmaktadır. Bu da özellikle kadınlar için güzel bir gelir kapısı oluşturmuştur."

Edirne, geçmişten itibaren bünyesinde farklı ulus ve kültürleri barındırdığı için zengin bir inanç merkezidir. Müslümanlar için önemli bir ibadethane olan ve Mimar Sinan'ın ustalık eserim dediği Selimiye Camii başta olmak üzere, Erken Osmanlı Mimarisi olan Eski Cami, Üç Şerefeli Cami, Dar- ül Hadis Camii, Muradiye Camii ve mevcut diğer camiler; Ortodoks Hıristiyanlar için önemli olan Sveti Konstantin Eleni Kilisesi ve Sveti Georgi Bulgar Kiliseleri; Avrupa'nın 3. Büyük sinagogu olan Edirne 


\section{Özlem Er ve Övünç Bardakoğlu}

Büyük Sinagog'u ve Bahailerin hac merkezi sayılan Bahai Evi Edirne'nin inanç turizmi çekim noktalarını oluşturmakta ve farklı dinlere ev sahipliği yapmanın hoşgörüsüyle ziyaretçilerini kabul etmektedir.

\section{Turizm Ürünü Çeşitlendirmesi}

Katılımcıların \% 89'u Edirne'de daha fazla turizm ürünü çeşidinin oluşturulabileceğini, şu anki mevcut ürünlerin yetersiz olduğunu belirtmiştir. Sadece bahar ve yaz dönemlerinde turistlerin şehri yoğun bir şekilde ziyaret ettiğini ifade eden katılımcılar, turizm ürünü sayısının fazlalaşması ile birlikte turizmin yılın 12 ayına yayılmasının mümkün olduğunu vurgulamışlardır. Bu çeşitlendirme kapsamında; nehirlerin turizme ve su sporlarına açılması gerekliliği (\%37), nehirlerin kıyısında yerel yemeklerin sunulabileceği restoranların faaliyete geçirilmesi (\%37), müze ve benzeri tarihi ve kültürel alanların açılması $(\% 26,3)$ ile ilgili fikirler ön plana çıkmaktadır.

\section{Tablo 2: Ürün Çeşitlendirme}

\begin{tabular}{|l|l|}
\hline Kullanılan İfadeler & n \\
\hline 1.Nehirlerin Turizm Amaçı Kullanımı & 7 \\
\hline 2. Yerel Restoranların Açıması & 7 \\
\hline 3. Tarihi ve Kültürel Alanların Turizme Açılması & 5 \\
\hline
\end{tabular}

Edirne'nin 3 nehrin (Meriç, Tunca, Arda) birleştiği bir kent olmasına rağmen nehirlerden yeterince yararlanılamadığını belirten katılımcılar, yağmur yağdığında altyapı eksikliği nedeniyle nehir taşkınlarının yaşanması gibi olumsuzlukların giderilmesinin önemine vurgu yapmışlardır.

Görüşme 11: "nehirlerin acil ıslahı gerekiyor... aynı nehrin ülke sınırının diğer tarafinda kalan kısmında her türlü aktivite yapılıyorken, bizim tarafta taşkınlarla birlikte hep sıkıntı yaratıyor... nehirler üzerinde tekne turları ya da su sporları yapmamamı için bir neden yok aslında... sadece üzerinde biraz çalışılmalı..."

Osmanlı İmparatorluğu'na ev sahipliği yaptığı ve birçok ulusu (Türk, Rum, Yahudi, Ermeni) bünyesinde barındırdığından geleneksel Edirne/Saray yemeklerinin turistlere sunulduğu restoranların açılması gerekliliği katılımcılar tarafından önemle belirtilmiştir. Şehirde geleneksel Edirne/Saray yemeklerinin gelecek kuşaklara aktarılabilmesi amacıyla yemek yarışmaları düzenlendiği de edinilen bilgiler arasındadır.

Her fırsatta Edirne'nin tarihi bir kent olduğunu vurgulayan katıımcılar Edirne'de Trak medeniyetine ait bir müze olmadığını, böyle bir 


\section{Kültürel Mirasın Sürdürülebilir Turizm Ürünü Çeşidi Olarak Değerlendirilmesi: Edirne Örneği}

müzeye ihtiyaç duyulduğunu belirtmişlerdir. Ayrıca Balkan Savaşları'nı yaşayan bir kent olarak Balkan Savaşları Müzesinin bulunmamasının eksiklik olduğu, özellikle Eski Osmanlı Sarayı başta olmak üzere diğer tarihi ve kültürel alanların restore edilerek turizme açılması gerektiği ulaşılan bulgulardandır.

\section{Kültürel Mirasın Sürdürülebilirliği}

Araştırma kapsamında görüşülen katılımcıların \%73,6'sı Edirne'deki kültürel kaynakların sürdürülebilirliğinin sağlanması için Valilik, Belediye ve Kültür Müdürlüğü'nün çalışmalarını Anıtlar ve Sitler Kurulu ile birlikte yürüttüğünü söyleyerek tarihi binaların envanterinin çıkarıldığını, onarım, restorasyon ve restitüsyon çalışmalarının yürütüldüğünü belirtmişlerdir. Tarihi elektrik fabrikasının, Makedon Kulesi'nin, Avrupa'nın 3. Büyük sinagogu olan ve Kaleiçi mevkiinde yer alan ve yıkık durumda olan Edirne Büyük Sinagogunun, Hıdırlık Tabyanın ve restore edilen tarihi birçok çeşmenin farkındalık yarattığı ifade edilmiştir. Ayrıca Arkeoloji Müzesi ile II. Bayezid Külliyesi Sağlık Müzesi'nin de teşhirinin yenilendiğini, Selimiye Camii çevresinin düzenlenmesi amacıyla arkeolojik çalışmaların yürütüldüğünü, Kırkpınar Yağlı Güreşleri'nin de yapıldığı yer olan Sarayiçi alanının ören yeri statüsüne kavuşması amacıyla çalışmalar yürütüldüğünü, tarihi taş köprülerin ışıklandıııması için çalışmalar yapıldığını, Ermeni, Rum ve Yahudilerden kalan tarihi konakların restore edilerek butik otel ya da lokanta olarak hizmete açıldığını belirtmişlerdir.

\section{Tablo 3: Kültürel Mirasın Sürdürülebilirliği}

\begin{tabular}{|l|l|}
\hline Kullanılan İfadeler & $\mathbf{n}$ \\
\hline 1.Tarihi Binaların Envanteri & 8 \\
\hline 2. Onarım ve Restorasyon & 8 \\
\hline 3. Müzelerin Yenilenmesi & 7 \\
\hline 4. Arkeolojik Kazılar & 7 \\
\hline 5. Kültürel Mirasın Öneminin Anlatılması & 6 \\
\hline 6. Sürdürülebilir Turizm Anlayışı Yok & 5 \\
\hline
\end{tabular}

Katııımclar, Edirne Kent Tarihi araştırmalarıyla geçmiş ve günümüz karşılaştırması yapıldığını belirtirken esnafa, yerel halka ve öğrencilere kültürel mirasın önemini anlatmak; kültürel değerleri korumak ve geleceğe aktarabilmek ve özellikle kültür turizminden pay alınabilmesi için turizm 


\section{Özlem Er ve Övünç Bardakoğlu}

bilinci oluşturulması amacıyla seminer ve konferanslar düzenlendiğini ifade etmişlerdir.

Katılımcıların \%26,3' ü Edirne'de sürdürülebilir bir turizm anlayışııın olmadığını, kamu ve yerel yönetim temsilcilerinin görev süreleri dolduğunda projelerin de yarım kaldığını belirtmişlerdir.

Görüşme 5: "birkaç tarihi bina dışında restorasyon yapılmadı, onlar da tamamen göstermelik... neredeyse her şiddetli yağmurda nehirler taşıyor, altyapı eksikliği çok fazla ve tabii ki turizm bunlardan olumsuz etkileniyor".

\section{Kültür Turizminin Gelişimi}

Katılımcıların \%74'ü Edirne'de kültür turizminin geliştirilmesi ile ilgili çeşitli önerilerde bulunmuştur. Edirne'nin kültür turizminde mevcut imajının daha iyi kavratılması ve yönetilmesi için yerelde ve genelde daha kapsamlı bir planlama yapılması gerektiğini söyleyen katılımcılar, bölgesel ortaklar ve potansiyel rakiplerin tam ve doğru tespit edilerek komşu illerle birlikte bir vizyon oluşturulmasını ve bu vizyon doğrultusunda hedef pazarların belirlenerek alıcılar için standart bir kalite güvence garantisi verilmesi gerektiğini vurgulamışlardır.

\section{Tablo 4: Kültür Turizminin Gelişimi}

\begin{tabular}{|l|l|}
\hline Kullanılan İfadeler & n \\
\hline 1. Alt ve Üst Yapı geliştirilmeli & 6 \\
\hline 2. Kent Belleği Müzesi kurulmalı & 6 \\
\hline 3. Tarihi Konakların Restorasyonu yapıımalı & 5 \\
\hline 4. Edirne Sarayı Ören Yeri Projesi & 4 \\
\hline
\end{tabular}

Edirne'nin imajını zedelememek, kültür turizmini geliştirmek, turizmi 12 aya yayabilmek ve daha fazla konaklamalı turist çekebilmek için öncelikle alt ve üst yapı eksikliklerinin giderilmesi gerektiğini ifade eden katılımcılar, turizm alanında görev alan tüm paydaşların işbirliği içerisinde çalışarak ortak hareket etmesi gerektiğini belirtmişlerdir.

Görüssme 2: "Edirne'de çok fazla tarihi konak var... belediye, otelciler, sivil toplum kuruluşları bir araya gelerek ne yapabiliriz diye düşünmeli, bunların her biri ayrı bir değer... restore edilerek müze, otel, restoran yapılabilir ve yerel halka istihdam sağlanabilir".

Kentte tematik alan ve müze düzenlemesine intiyaç duyulduğunun altını çizen katıımcılar, farklı bölümlerden (Kırkpınar, göç, hamam, 


\section{Kültürel Mirasın Sürdürülebilir Turizm Ürünü Çeşidi Olarak Değerlendirilmesi: Edirne Örneği}

gastronomi, vb.) oluşacak bir kent belleği müzesi projesinin vakit kaybetmeden hayata geçirilmesi gerektiğini ifade etmişlerdir.

2010 yilında UNESCO Somut Olmayan Kültürel Miras Listesine giren ve Edirne'yi sadece yurt içinde değil aynı zamanda yurt dışında da tanıtan ve Edirne'nin kültür turizmine hizmet eden Tarihi Kırkpınar Yağı Güreşleri'ne uluslararası bir nitelik kazandırıması gerekliliği de elde edilen bulgular arasındadır.

\section{SONUÇ VE ÖNERİLER}

Bu araştırma kapsamında, kültür turizmi ve sahip olduğu kültürel mirasın çekim gücü ile turist kabul eden bir destinasyon olan Edirne ilinin mevcut turizm ürün ve çekicilikleri ile oluşturulabilecek yeni ürünler belirlenmiş; sürdürülebilir bir kültür turizmi için neler yapılması gerektiği incelenmiştir. Bu amaçla Edirne'de turizm alanında faaliyet gösteren kamu sektörü, özel sektör, yerel yönetim, sivil toplum kuruluşları ile üniversite temsilcilerinden oluşan 19 katıımcıya araştırma sorunsalı ile ilgili 4 soru yöneltilmiştir. Elde edilen bulgular doğrultusunda önerilerde bulunulmaya çalışılmıştır.

Bir destinasyonda turizmin hangi şekilde geliştirileceğine karar vermek amacıyla öncelikle destinasyonun çekim güçlerinin neler olduğu belirlenmelidir (Balmer ve Chen, 2016; Guan ve Jones, 2015; Wu, Xie ve Tsai, 2015). Turistik destinasyonlarda turizm etkinlikleri turizm ürünleri etrafında geliştirilmekte ve turizm ürünü çeşitliliği ne ölçüde fazlaysa destinasyonun çekim gücü de o kadar artmaktadır (Benur ve Bramwell, 2015; Suess ve Mody, 2016). Edirne, Türkiye'nin Avrupa'ya açlan kapısı ve zengin kültür varlıkları bakımından önemli destinasyonlarından biridir. Edirne, Osmanlı İmparatorluğu'na 92 yıl başkentlik yapmış, farklı etnik köken ve dinleri barındırdığı için kendine has bir kültüre sahiptir. Dolayısıyla Edirne'de turizm ürünlerinin kaynağını tarihi ve kültürel değerler oluşturmaktadır. Ancak kentin, tarihi ve kültürel varlıklara sahip olmasına rağmen bu varlıkların büyük bir bölümünün değerlendirilemediği ve gerektiği şekilde tanıtımının yapılamadığı çalışma sonucunda tespit edilmiştir. Bulgular Saarinen, Moswete ve Monare'nin (2014) çalışmaları ile benzerlik göstermektedir. Sadece Selimiye Camii, Kırkpınar Yağlı Güreşleri, Hıdrellez Şenliği, Tava Ciğeri gibi belli başlı kültür hazineleri ön plana çıkarılmış ve diğer kültürel değerler arka planda kalmıştır. Başarılı bir turizm gelişim planlaması için şehrin sahip olduğu bu değerler teker teker ele alınmalı, etkili pazarlama politikaları ile turistlerin destinasyona gelmesi için çalışılmalıdır (Inskeep, 1991; Hacıoğlu, 2008). 


\section{Özlem Er ve Övünç Bardakoğlu}

Edirne, inanç turizmi açısından son derece önemli bir merkezdir. Kent, dört farklı dinin (Müslümanlık, Hıristiyanlık, Musevilik ve Bahailik) kutsal mekanlarına ev sahipliği yapmaktadır. Selimiye Camii, Müslümanlar için kutsal kabul edilmektedir ve caminin UNESCO Dünya Kültür Mirası Listesi'ne girmesiyle birlikte dünyaca bilinirliği artmıştır. Ancak, caminin etrafında tarihi dokuya uygun olmayan satış yerlerinin olması ve esnafın turiste kontrolsüz yaklaşımı Edirne kültür turizmini olumsuz etkilemektedir. Bu satış yerlerinin tarihi dokuya uygun hale getirilmesi ve esnafa turizm eğitiminin verilmesi, caminin minyatürlerinin yapılarak hediyelik eşya olarak satışa sunulmasının turizm gelişimini olumlu etkileyeceği düşünülmektedir. Böylece hem kentin tanıtımı yapılır hem de yerel halka istihdam yaratılır.

Meriç Nehri kıyısında yer alan Kent Ormanı ve Karaağaç bölgesi, yerel halk ve turistler için kentin en önemli rekreasyon alanıdır. Ancak şiddetli yağışlarda nehir yatağındaki taşkınlar, etrafında bulunan az sayıdaki tesisin zarar görmesine ve uzun süre hizmete kapalı olmasına neden olmaktadır. Bunun yanında yürüme ve bisiklet parkuru bulunmaması ve nehirlerin ıslah çalışması yapılmaması dolayısıyla su sporlarından yararlanılamamaktadır. Bu doğrultuda; nehirleri ıslah çalışmaları, yeni rekreasyon çalışmalarının yapılması, uluslararası yarışmaların düzenlenmesi şehre yönelik talebi arttıracak etkinliklerdir.

Turizm faaliyetlerinin mevsimselliğinin önlenmesi amacıyla tüm yıla yayılacak tur programlarının oluşturulması ve şehre çoğunlukla hafta sonu günübirlik gelen turistin geceleme yapmasını sağlayacak tur programlarının hafta içi günlere de dağıtılması konaklama potansiyelini arttıracaktır. Çünkü şehirde günübirlik ziyaret sayısının fazla olması konaklama sektörüne gerekli yatırımın yapılmasını engellemiştir. Turizm ürünlerinin çeşitlendirilmesi ve sayısının arttırımasıyla bu sorunun aşılacağı düşünülmektedir.

Yiyecek- içecek işletmelerinde ise neredeyse hiç Osmanlı mutfağına yer verilmemesi, üst gelir grubuna hitap eden restoran olmaması, restoranlarda içki satışı yapılmaması ve restoranların esnaf lokantası şeklinde hizmet vermesi yöresel lezzetleri tatmak isteyen kültür turistini olumsuz etkilemekte ve bu durum Edirne kültür turizminin gelişmesindeki eksikliklerden biri olarak değerlendirilmektedir. Şehirde turizm alanında faaliyet gösteren paydaşların bir ortak akıl geliştirerek bu soruna çözüm bulmaları, değeri her geçen gün hızlı bir şekilde artan gastronomi turizminden daha fazla pay alınabilmesi adına son derece önemlidir. Ayrıca otopark sorunu bulunan kentte özellikle tur otobüslerinin park edebileceği alanlar oluşturulmalı ve kentin dışında olmasına rağmen park sorunu yaşanılan ve 2004 yılında Avrupa'nın en iyi sağlık müzesi ödülünü kazanan 


\section{Kültürel Mirasın Sürdürülebilir Turizm Ürünü Çeşidi Olarak Değerlendirilmesi: Edirne Örneği}

II. Bayezid Külliyesi Sağlık Müzesi'nde de bir park alanı oluşturulması akılcı olacaktır. Şehirdeki alt ve üst yapı eksikliklerinin tespit edilerek ilgili kurumlar tarafından giderilmesi çalışmalarına hızlıca başlanmalıdır.

Sürdürülebilir turizm faaliyetlerinin gerçekleşmesi için yerel halkın bakış açısı önemlidir. Yerel halk, yaşadığı yörenin doğal ve kültürel değerleri sayesinde ekonomik açıdan gelir elde ettiği takdirde bu değerleri koruma bilincini de edinecektir. Edirne'de yerel halkın en büyük eksikliklerinden biri de turizm ve turizmin sürdürülebilirliği konusundaki bilgisizliktir. Yerel halk, turizm ve sürdürülebilirliği konusunda bilgilendirilerek gerekli çalışma ve örgütlenmelerin içine dahil edilmeli, halka, turizmden elde edeceği ekonomik kazanç anlatılarak kaynakların korunmasına katkıda bulunması sağlanmalıdır. Böylece destinasyonda sürdürülebilir turizm anlayışı oluşturulabilecektir.

Yerel yönetimler kadar turizm sektöründe etkili olan ve hizmet veren kuruluş ve yatırımcılara da görev düşmektedir. Bu kuruluşlar ve yatıımcılar, kentte kültürel turizmin sürdürülebilirliği için projeler üretmeli, belirli periyotlarla bir araya gelerek fikir alışverişi yapmalı, sürdürülebilir turizm ile ilgili yenilikleri takip etmeli, turizmin sürdürülebilirliğine aykırı durumlarda işbirliği içerisinde kamuoyu oluşturmalı, sosyal sorumluluk projelerinde yer alarak kentin tanıtımına destek vermeleri sağlanmalıdır.

Edirne'de ticaret ve turizm hayatının geliştirilmesi amacıyla Turizm Master Planı hazırlanmaktadır. Bu projenin tamamlanmasıyla birlikte Edirne'de turizmin olumlu yönde gelişeceği düşünülmekte ve yerel halka istihdam yaratması beklenmektedir.

Araştırma, Edirne ilinde turizm ile doğrudan ilgili kamu sektörü, özel sektör, yerel yönetim ve sivil toplum kuruluşlarının temsilcileri ile sınırlıdır. Nitel araştırma yöntemi kullanılarak görüşme tekniği ile elde edilen sonuçların ve sunulan önerilerin Edirne ile ilgili gerçekleştirilecek daha detaylı araştırmalara yol gösterici olması beklenmektedir. Literatürde turizm ürünü ve sürdürülebilir turizm ile ilgili örnek çalışmalar bulunmasına rağmen turizm ürünü olarak kültürel miras turizminin sürdürülebilirlik ilkeleri doğrultusunda incelenmesinin literatürdeki boşluğu dolduracağı ve gelecekte yapılacak çalışmalara katkı sağlayacağı düşünülmektedir.

\section{KAYNAKÇA}

Balmer, J. ve Chen, W. (2016). Corporate Heritage Tourism Brand Attractiveness And National Identity. Journal of Product \& Brand Management, 25(3), 223-23. 


\section{Özlem Er ve Övünç Bardakoğlu}

Batman, O. ve Oğuz, S.Ç. (2008). Kültür Turizmi, N. Hacıoğlu \& C. Avcıkurt (Ed.) Turistik Ürün Çeşitlendirmesi (ss. 189-208). Ankara: Nobel Yayın Dağııım.

Benur, A. ve Bramwell, B. (2015). Tourism Product Development And Product Diversification In Destinations. Tourism Management 50, 213-224.

Bramwell, B. (1998). User Satisfaction And Product Development In Urban Tourism. Tourism Management, 19(1), 35-47.

Burkart, A.j. ve Medlik, S. (1981). Tourism, Past, Present and Future. Londra: Butterworth- Heineman.

Chhabra, D. (2009). Proposing a Sustainable Marketing Framework for Heritage Tourism, Journal of Sustainable Tourism, 17(3), 303-320.

Du Cros, H. (2001). A New Model to Assist in Planning For Sustainable Cultural Heritage Tourism. International Journal of Tourism Research 3, 165-170.

Çekül Vakfı (2012). Sürdürülebilir Kültür Turizmi İçin Kamu -Yerel - Sivil İşbirliği. http://www.cekulvakfi.org.tr/files/dosyalarhaber/surduru lebilir_kultur_turizmi_klavuzu.pdf (25.05.2015)

Dedehayır, H. (2014). Sürdürülebilir Kültür Turizmi. http://cekulvakfi.org.tr/makale/surdurulebilir-kultur-turizmi (16.08.2016)

Demir, M. ve Demir, Ş.Ş. (2004). Turistik Ürün Çeşitlendirme Kapsamında Futbol Turizmi: Antalya Bölgesinde Bir Araştırma. Dokuz Eylül Üniversitesi Sosyal Bilimler Enstitüsü Dergisi, 6(1), 94-116.

Dinçer, F.İ. ve Ertuğrul, S.M. (2009). Turizm İşletmelerinin Pazarlamasında Ürün (Product), C. Avcıkurt \& Ş. Demirkol (Ed.), Turizm İşletmelerinin Pazarlamasında 7P 7C (ss. 49-74). İstanbul: Değişim Yayınları.

Doswell, R. (1997). Tourism: How Effective Management Makes The Difference. Oxford: Butterworth-Heinemann.

Guan, J. ve Jones, D. (2015) The Contribution of Local Cuisine to Destination Attractiveness: An Analysis Involving Chinese Tourists' Heterogeneous Preferences. Asia Pacific Journal of Tourism Research, 20(4), 416-434.

Hacıoğlu, N. (1989). Turizm Pazarlaması, Bursa: Uludağ Üniversitesi Basımevi.

Hacıoğlu, N. (2008). Turizm Pazarlaması, Ankara: Nobel Yayın Dağıım.

Inskeep, E. (1991). Tourism Planning An Integrated And Sustainable Development Approach. New York: Van Nostrand Reinhold. 


\section{Kültürel Mirasın Sürdürülebilir Turizm Ürünü Çeşidi Olarak Değerlendirilmesi: Edirne Örneği}

Ismagilova, G.N., Safiullin, L.N. ve Bagautdinova, N.G. (2014). Tourism Development In The Region Based On Historical Heritage. Life Science Journal 11, 363-367.

Kozak, M. (2014). Bilimsel Araştırma: Tasarım, Yazım ve Yayım Teknikleri. Ankara: Detay Yayınclık.

$\mathrm{Li}$, Y. ve Hunter, C. (2015). Community Involvement For Sustainable Heritage Tourism: A Conceptual Model. Journal of Cultural Heritage Management and Sustainable Development, 5(3), 248-26.

Loulanski, T. ve Loulanski, V. (2011). The Sustainable Integration Of Cultural Heritage And Tourism: A Meta-Study. Journal of Sustainable Tourism, 19(7), 837-862.

Mowforth, M. ve Munt, I. (1998). Tourism and Sustainabilty, Londra: Routledge.

Murphy, P., Pritchard, M. ve Smith, B. (2000). The Destination Product And İts İmpact On Traveller Perceptions. Tourism Management 21, 43 52.

Olalı, H. ve Timur, A. (1988). Turizm Ekonomisi. İzmir: Ofis Ticaret Matbaaclık Şti.

Olalı, H. (1982). Turizm Politikası ve Planlaması. İzmir: Ege Üniversitesi Matbaası.

Özdoğan, N.O. (2014). Sürdürülebilir Turizm ve Kültürel Miras, M. Kozak (Ed.) Sürdürülebilir Turizm Kavram- Uygulamalar (ss. 47-60). Ankara: Detay Yayıncilık.

Petkova, E. ve Marınov, V. (2014). Development of Diversified Tourism Destination Products - A Case Study of Tourism Destination, Municipality of Sofia, Bulgari. Journal of Enviromental and Tourism Analyses, 2(1), 33-47.

Saarinen, J., Moswete, N. ve Monare, M. (2014). Cultural Tourism: New Opportunities For Diversfying The Tourism İndustry In Botswana. Bulletin of Geography. Socio-economic Series No. 26, 7-18.

Sarkım, M. (2007). Sürdürülebilir Turizm Kapsamında Turistik Ürün Çeşitlendirme Politikaları ve Antalya Örneği (Yayınlanmamış Doktora Tezi). Dokuz Eylül Üniversitesi, Sosyal Bilimler Enstitüsü, İzmir.

Suess, C. ve Mody, M.(2016). Gaming Can Be Sustainable Too! Using Social Representation Theory To Examine The Moderating Effectes Of Tourism Diversification On Residents' Tax Paying Behavior. Tourism Management, 56, 20-39.

Swarbrooke, J. (1998). Sustainable Tourism Management. Wallingford: CABI Publishing. 


\section{Özlem Er ve Övünç Bardakoğlu}

Uslu, A. ve Kiper, T. (2006). Turizmin Kültürel Miras Üzerine Etkileri: Beypazarı/ Ankara Örneğinde Yerel Halkın Farkındalığı, Tekirdağ Ziraat Fakültesi Dergisi, 3(3), 305-314.

Uygur, S.M. ve Baykan, E. (2007). Kültür Turizmi ve Turizmin Kültürel Varlıklar Üzerindeki Etkileri, Ticaret ve Turizm Eğitim Fakültesi Dergisi, 2, 30-49.

Ünsal, D. ve Pulhan, G. (2012). Türkiye'de Kültürel Mirasın Anlamı ve Yönetimi. A. Aksoy ve D. Ünsal (Ed.) Kültürel Miras Yönetimi İçinde (ss. 30-65). Eskişehir: Anadolu Üniversitesi Yayınları.

Wu, T., Xie, P. ve Tsai, M. (2015). Perceptions of Attractiveness or Salt Heritage Tourism: A Tourist Perspective. Tourism Management, 51, 201-209.

Yıldırım, A. ve Şimşek, H. (2008). Sosyal Bilimlerde Nitel Araştırma Yöntemleri. Ankara: Seçkin Yayıncılık. 